ROCZNIKI PEDAGOGICZNE

Tom 11(47), numer specjalny - 2019

DOI: http://dx.doi.org/10.18290/rped.2019.11s-31

ANDRZEJ WOŹNIAK

\title{
BADANIA WŁASNE KORELACJI ZMIENNYCH PRACY SKAZANEGO W KONTEKŚCIE PROCESU RESOCJALIZACJI PENITENCJARNEJ
}

\section{WSTĘP}

„Praca dla więźniów” to zainicjowany przez Wiceministra Sprawiedliwości Patryka Jakiego w 2016 r. oraz realizowany przez Służbę Więzienną program wspierania szeroko rozumianej readaptacji społecznej osób przebywających w zakładach karnych i aresztach śledczych, a w szczególności ich aktywizacji zawodowej. Należy pamiętać, iż skazani przed 2016 r. również pracowali, ale na nieco innych zasadach (por. Pierzchała, 2011).

Obecnie podstawę funkcjonowania programu stanowią przepisy następujących aktów prawnych:

- ustawy z dnia 28 sierpnia 1997 r. o zatrudnianiu osób pozbawionych wolności (Dz. U. z 2014 r., poz. 1116, z późn. zm.),

- ustawy z dnia 6 czerwca 1997 r. Kodeks karny wykonawczy (Dz. U. 1997, nr 90, poz. 557, z późn. zm.),

- rozporządzenia Ministra Sprawiedliwości z dnia 30 maja 2017 r. w sprawie Funduszu Aktywizacji Zawodowej Skazanych oraz Rozwoju Przywięziennych Zakładów Pracy (Dz. U. z 2017 r., poz. 1069), a wcześniej rozporządzenia Ministra Sprawiedliwości z dnia 23 stycznia 2012 r. (Dz. U. z 2014 r., poz. 53).

W artykule Agaty Łukasiewicz pt. Okresowe oceny postępów resocjalizacyjnych więźniów (,Rzeczpospolita” z 9.12.2016) czytamy m.in.:

[...] Skazanego poddaje się okresowym ocenom postępów w resocjalizacji. Robi się to nie rzadziej niż co sześć miesięcy. [...] Przy dokonywaniu ocen okresowych

ANDRzeJ WoźnIAK - emerytowany oficer Służby Więziennej, Warszawa; e-mail: andrzejwozniak@vp.pl; ORCID: 0000-0003-1851-9743 
w postępach skazanego w resocjalizacji komisja penitencjarna uwzględnia: stosunek skazanego do popełnionego przestępstwa; stopień przestrzegania przez niego porządku i dyscypliny; stosunek do pracy czy charakter kontaktów z rodziną i wywiązywanie się z obowiązku łożenia na jej utrzymanie. [...] Nie bez znaczenia jest też zachowanie skazanego wobec innych skazanych i przełożonych oraz zmiany w zachowaniu od ostatniej oceny. Jeśli widać poprawę, ocena jest wyższa (Łukasiewicz, 2018). Te zagadnienia w pewnym sensie stały się przedmiotem badań i podstawą napisania tego artykułu. Metodologią wykorzystaną przy tworzeniu przedmiotowej publikacji stało się przeprowadzenie krytycznej analizy literatury, aktów prawnych i innych dokumentów, w tym dostępnych zasobów Internetowych. Badania zostały przeprowadzone w Zakładzie Karnym w Opolu Lubelskim w marcu 2018 roku na wybranych 56 osobach, odbywających karę pozbawienia wolności. Zastosowano w nich metodę ankietową, a w obliczeniach - współczynnik korelacji liniowej Pearsona.

Jak podaje Centralny Zarząd Służby Więziennej (CZSW), ,Jednostka [Zakład Karny w Opolu Lubelskim - A. W.] jest zakładem typu zamkniętego dla mężczyzn odbywających karę pozbawienia wolności po raz pierwszy oraz młodocianych, z dwoma wydzielonymi oddziałami dla tymczasowo aresztowanych oraz (od dnia 10 października 2016 roku) z wydzielonym oddziałem zakładu typu półotwartego dla mężczyzn odbywających karę pozbawienia wolności po raz pierwszy (wyłącznie skazani przebywający w jednostce w związku z realizacją umowy o zatrudnienie zewnętrzne). Pojemność jednostki wynosi 627 miejsc zakwaterowania. Oficjalne otwarcie zakładu nastąpiło w dniu 5 października 2009 roku. Od dnia 12 października rozpoczęto zasiedlanie pawilonów mieszkalnych" (Statystyka, 2018a, 2018b, tab. 3). W marcu 2018 r. w tej jednostce penitencjarnej ewidencyjna liczba osadzonych wynosiła 593 osoby, w tym tymczasowo aresztowanych 60 osób.

Resocjalizacja, w znaczeniu, jakie nadają jej klasycy myśli resocjalizacyjnej w Polsce [Czapów i Jedlewski, 1971], to proces swoistej naprawy moralnej i obyczajowej człowieka, przypominający przebieg zdrowienia z przewlekłej choroby, którą jest wykolejenie przestępcze lub obyczajowe [...]. Resocjalizacja jest odmianą procesu wychowawczego, który z jednostki wadliwie przystosowanej do wymogów życia społecznego czyni jednostkę ponownie zsocjalizowaną, tzn. uspołecznioną, samodzielną i twórczą (Kalinowski, 2008, s. 234-235).

Współcześnie termin „resocjalizacja” w ujęciu Marka Konopczyńskiego pojmowany ex definitione, „oznacza ponowną socjalizację, a więc powtórne uspołecznienie jednostki nieprzystosowanej społecznie w celu umożliwienia jej poprawnego funkcjonowania w powszechnie akceptowanych rolach życiowych i społecznych" (Konopczyński, 2015, s. 9). 
Prawdą pedagogiczną - według Lesława Pytki - którą się przyjmuje, jest prawda wewnętrznej transformacji człowieka z problemami i wiara w możliwości poprawy niekiedy dramatycznej i jakby beznadziejnej sytuacji (Pytka, 2008, s. 97). Określając resocjalizację, Pytka stwierdza, że „nie ma jednej resocjalizacji, której zastosowanie gwarantowałoby sukces w każdym przypadku" (Pytka, 2006, s. 268), i wskazuje potrzebę indywidualnego podejścia do każdej osoby. Wśród typów resocjalizacji wymienia resocjalizację jako: modyfikację zachowań, zmianę społecznej przynależności, przebudowę emocjonalną, wrastanie w kulturę i zaspokajanie potrzeb, kształtowanie prawidłowych postaw społecznych, dostosowanie sytuacji do nieletniego, „nawrócenie” na wartości wyższego rzędu, reintegrację społeczną jednostki, autoresocjalizację (Pytka, 2006, s. 268-270).

Według Kazimierza Pierzchały, wieloletniego kapelana więziennego,

Resocjalizacja to nauka i praktyka społeczna, określająca zakres działań wychowawczych, opiekuńczych i terapeutycznych. Jest to proces zmierzający do wykształcenia u osób niedostosowanych społecznie zmian w obszarze samoświadomości, samowychowania, samopotwierdzenia i samorefleksyjności (Pierzchała, 2017, s. 95; por. Pierzchała, 2011; 2013; 2016).

\section{KILKA SŁÓW O KORZYŚCIACH W ZATRUDNIANIU WIĘŹNIÓW}

Jak podaje na swoich stronach CZSW, „Praca dla więźniów” jest projektem bez precedensu w historii polskiego więziennictwa. Tylko w ciągu dwóch lat realizacji programu zatrudnienie skazanych zwiększyło się o prawie 12 tysięcy osadzonych, a wskaźnik powszechności zatrudnienia osadzonych przekroczył niemotywowaną wcześniej wartość $57,2 \%$. Obecnie pracuje ponad 36,5 tys. osób pozbawionych wolności (dane na koniec grudnia 2018 r.). Nigdy w historii III RP nie pracowało tylu skazanych. Swoje obowiązki skazani wykonują prawidłowo, często z dużym zaangażowaniem. Dzięki wprowadzeniu programu obniżają się także koszty utrzymania więźniów przez obywateli. W 2018 roku skazani przepracowali nieodpłatnie w skali kraju prawie 2 miliony roboczogodzin o wartości ponad 23 milionów złotych (dane po 11 miesiącach). Na podkreślenie zasługuje fakt, że realizacja rządowego programu „Praca dla więźniów” jest finansowana przede wszystkim przez samych skazanych, a nie z pieniędzy podatników. Dzięki programowi w 2018 r. kwota potrąceń, z wynagrodzeń osadzonych mających zobowiązania alimentacyjne, wyniosła prawie 13 milionów złotych (dane po 11 miesiącach). Im więcej osadzonych pracuje, tym większe środki finansowe z potrąceń od ich wynagrodzeń przeznaczane są na Fundusz Aktywizacji Zawodowej Skazanych oraz 
Rozwoju Przywięziennych Zakładów Pracy, z którego finansuje się budowę hal produkcyjnych, w których zatrudnieni będą osadzeni. Istnieje możliwość wypłacania przedsiębiorcom ryczałtu z tytułu zwiększonych kosztów zatrudnienia osób pozbawionych wolności, który w wyniku zainicjowanych w ramach programu działań legislacyjnych Ministerstwa Sprawiedliwości oraz Służby Więziennej wzrósł z 20\% do 35\% wartości przysługujących skazanym wynagrodzeń (CZSW, 2018).

Zanim więźniowie trafią do pracy, przechodzą specjalne szkolenie. Uczą się oni, jak rozmawiać z innymi pracownikami, jak odpowiadać na ich pytania. Podobne szkolenie przeprowadza się też dla pracowników firm. Im z kolei tłumaczy się, o co powinni pytać nowych kolegów. Skazani, którzy dostają pracę, wiedzą, że są pod szczególną obserwacją. Przedsiębiorstwo i zakład karny zwracają uwagę przede wszystkim na to, aby nie dochodziło do kradzieży, bójek, spożywania alkoholu czy brania narkotyków. Takie wybryki bardzo rzadko zdarzają się więźniom zatrudnionym w przedsiębiorstwach (Blikowska, 2007).

Więźniowie pracujący mają umowy o pracę oraz przysługują im świadczenia pracownicze. Dla wielu z nich jest to pierwsza praca na umowę. Wcześniej, jeśli się zdarzało, że pracowali, to głównie „na czarno”, bez żadnych świadczeń. Dla skazanych legalna praca jest czymś nowym. Należy pamiętać, że praca jest jednym z najważniejszych elementów programu resocjalizacyjnego. Dzięki statusowi pracownika każdy z uczestniczących w programie skazanych wzmacnia poczucie własnej wartości (Blikowska, 2007; Pierzchała, 2011; 2016).

Za pracę skazani otrzymują określoną płacę. Środki są przelewane na konto zakładu, a dopiero później dostają je pracownicy. Dzięki pieniądzom skazani mogą robić zakupy w więziennej kantynie i w ten sposób odciążyć finansowo rodziny. Niektórzy część pieniędzy przekazują najbliższym. Skazani najczęściej pracują ciężko, nawet nocą, bardzo sumiennie podchodzą do swojej pracy i na ogół są lepsi od wielu pozostałych pracowników. Pracę najczęściej otrzymują osoby z niskimi wyrokami, skazani po raz pierwszy, za drobne przestępstwa. Dla zachowania bezpieczeństwa i porządku w przedsiębiorstwie przebywa zawsze funkcjonariusz Służby Więziennej (Blikowska, 2007).

W 2018 roku w polskich więzieniach przebywało średnio 74077 osadzonych, z czego zdecydowana większość - 66650 - miała wyroki skazujące. Reszta to osoby tymczasowo aresztowane. Jak wynika ze statystyk CZSW, niemal co czwarty $(22,9 \%)$ osadzony pracował. Płatne zatrudnienie miało 16969 osób, z czego 16 to były osoby tymczasowo aresztowane. Powszechność wskaźnika zatrudnienia osadzonych to $54,3 \%$ (Statystyka, 2018b, tab. 46), przy średniej stawce za roboczogodzinę 13,34 zł (tamże, tab. 50). Zatrudnienie osadzonych w przywięziennych przedsiębiorstwach państwowych i instytucjach gospodarki budżetowej wyniosło średnio za 2018 rok 1987 osób (tamże, tab. 48). Statystyki podają również 
przyczyny niezatrudnienia, m.in. średni wskaźnik bezrobocia za 2018 r. - 11,7\% (tamże, tab. 49). Ważną informacją, którą można pozyskać ze statystyki CZSW, jest m.in. wielkość średniej kwoty przekazanej w roku 2018 osobom uprawnionym z tytułu alimentów, która wyniosła 201,91 zł (Statystyka, 2018b, tab. 51).

\section{METODOLOGIA BADAŃ}

W przypadku, gdy obie zmienne są przedziałowe' ${ }^{1}$ a korelacja jest liniowa ${ }^{2}$, można zastosować współczynnik korelacji Pearsona $r_{x y}$. Współczynnik Pearsona najlepiej odzwierciedla zależność między zmiennymi. Dlatego należy go stosować zawsze, gdy pozwalają na to warunki.

Obliczanie współczynnika korelacji liniowej Pearsona (Krajewska, 2001, s. 89-94; Lking, Minium, 2009, s. 177-180; Kožuh, 2011, 69-83):

$$
r=\frac{S S_{x y}}{\sqrt{S S_{x} S S_{y}}}
$$

$r / R$ - współczynnik korelacji liniowej Pearsona

$x_{i} ; y_{i}-$ wartości zmiennych $(x$ i $y)$

$S S_{x y}$ - moment iloczynowy Pearsona

$S S_{x}$ - suma kwadratów odchyleń od średniej zmiennej $x$

$S S_{y} \quad$ - suma kwadratów odchyleń od średniej zmiennej $y$

$\bar{x}$ - średnie arytmetyczne zmiennych $(x$ i $y)$

$n$ - liczebność zbiorowości

gdzie:

$$
\begin{array}{r}
\sum\left[\left(x_{i}-\bar{x}\right)\left(y_{i}-\bar{y}\right)\right] \\
S S_{x y}=\sum x_{i} y_{i}-\frac{\sum x_{i} \sum y_{i}}{n} \\
r(n-1)^{n}
\end{array}
$$

${ }^{1}$ Skala interwałowa (przedziałowa) - rodzaj skali pomiarowej. Zmienna jest na skali interwałowej, gdy różnice między dwiema jej wartościami dają się obliczyć i mają interpretację w świecie rzeczywistym, jednak nie ma sensu dzielenie dwóch wartości zmiennej przez siebie. Innymi słowy, określona jest jednostka miary, jednak punkt zero jest wybrany umownie. Przykłady zmiennych interwałowych: daty, np. data urodzenia, temperatura w stopniach Celsjusza, oceny (Kožuh, 2011, s. 69).

${ }^{2}$ Linia regresji może być linią krzywą lub prostą (oczywiście: tylko częścią prostej). W przypadku, gdy linia jest krzywa, występuje korelacja nieliniowa (krzywoliniowa), gdy linia jest prosta - korelacja jest liniowa (Kožuh, 2011, s. 66). 
oraz zmienna $x$

$$
\begin{gathered}
\sum\left(x_{i}-\bar{x}\right)^{2} \\
S S_{x}=\sum\left(x^{2}\right)-\frac{\left(\sum x\right)^{2}}{n} \\
S^{2}(n-1)^{n}
\end{gathered}
$$

i podobnie druga zmienna $y$ :

$$
\begin{gathered}
\sum\left(y_{i}-\bar{y}\right)^{2} \\
S S_{y}=\sum\left(y^{2}\right)-\frac{\left(\sum y\right)^{2}}{n} \\
S^{2}(n-1)^{n}
\end{gathered}
$$

Interpretacja wyników korelacji. Wyrazem liczbowym korelacji jest współczynnik korelacji (r), zawierający się w przedziale [-1; 1]. Korelacja dodatnia (wartość współczynnika korelacji od 0 do 1) informuje, że wzrostowi wartości jednej cechy towarzyszy wzrost średnich wartości drugiej cechy, natomiast korelacja ujemna (wartość współczynnika korelacji od -1 do 0) informuje, że wzrostowi wartości jednej cechy towarzyszy spadek średnich wartości drugiej cechy.

Siła związków korelacyjnych. Najważniejsza jest istotność korelacji:

- poniżej 0,2 - korelacja słaba (praktycznie brak związku),

- 0,2-0,4 - korelacja niska (zależność wyraźna),

- 0,4-0,6 - korelacja umiarkowana (zależność istotna),

- 0,6-0,8 - korelacja wysoka (zależność znaczna),

- 0,8-0,9 - korelacja bardzo wysoka (zależność bardzo duża),

- 0,9-1,0 - zależność praktycznie pełna.

Badaniu ankietowemu poddano 56 skazanych Zakładu Karnego w Opolu Lubelskim poprzez zadanie im czterech pytań zamkniętych z zakresu przedmiotowego artykułu. Odpowiedziami w ankietach było określenie swoich preferencji w danej zmiennej w skali 1-5, gdzie: 1 oznacza - bardzo niskie, 2 - niskie, 3 - przeciętne, 4 - wysokie, 5 - bardzo wysokie.

Przy każdym pytaniu były też osoby, które nie wypowiedziały się w danej kwestii (wstrzymały się od odpowiedzi), co również uwzględnia zaprezentowana analiza. Biorąc pod uwagę szczupłość miejsca - pierwsze badanie przeprowadzone zostało z pokazaniem całej procedury, a pozostałe uwzględniały 
tylko wyniki końcowe, z naszkicowaniem punktowego wykresu rozrzutu, wraz z linią trendu oraz podsumowaniem istotności korelacji zmiennych.

3. BADANIA WŁASNE

CZY POMIĘDZY ZMIENNYMI ISTNIEJE KORELACJA? JEŻELI TAK, TO JAKA?

PYTANIE 1

CZY TWOIM ZDANIEM PRACA SKAZANEGO JEST RÓWNIE WAŻNA JAK JEGO RESOCJALIZACJA?

$x$ - ważność wykonywanej pracy przez skazanego

$y$ - ważność postępów w resocjalizacji skazanego

Tabela pomocnicza

\begin{tabular}{|c|c|c|c|c|c|c|c|c|}
\hline \multirow{2}{*}{ Oceny } & \multirow{2}{*}{$\mathrm{x}_{\mathrm{i}}$} & \multirow{2}{*}{$y_{i}$} & $x_{i}-\dot{x}$ & $y_{i}-\bar{y}$ & $\left(x_{i}-\dot{x}\right)\left(y_{i}-\bar{y}\right)$ & $\left(x_{i}-\dot{x}\right)^{2}$ & $\left(y_{i}-\bar{y}\right)^{2}$ & \multirow{2}{*}{$y^{\prime}=a+b x$} \\
\hline 1 & 2 & 3 & 4 & 5 & $S S_{x y}$ & $S S_{x}$ & $S S_{y}$ & \\
\hline 1 & 7 & 5 & $-2,333$ & $-4,333$ & 10,11 & 5 & 8 & 9 \\
\hline 2 & 5 & 7 & $-4,333$ & $-2,333$ & 10,11 & 18,78 & 5,44 & 4,71 \\
\hline 3 & 9 & 8 & $-0,333$ & $-1,333$ & 0,44 & 0,11 & 1,78 & 8,98 \\
\hline 4 & 9 & 10 & $-0,333$ & 0,667 & $-0,22$ & 0,11 & 0,44 & 8,98 \\
\hline 5 & 21 & 22 & 11,667 & 12,667 & 147,78 & 136,11 & 160,44 & 21,78 \\
\hline brak & 5 & 4 & $-4,333$ & $-5,333$ & 23,11 & 18,78 & 28,44 & 4,71 \\
\hline$\sum$ & 56 & 56 & & & 191,33 & 179,33 & 215,33 & \\
\hline
\end{tabular}

Źródło: opracowanie własne; $n=6$; średnie arytmetyczne obydwu zmiennych jest równa i wynosi $\bar{x}_{i} \bar{y}=9,333(56: 6)$.

$r=\frac{S S_{x y}}{\sqrt{S S_{x} S S_{y}}}=\frac{191,33}{\sqrt{179,33 * 215,33}}=0,974$

Dla skonstruowania punktowego wykresu rozrzutu korelacji liniowej Pearsona oraz linii trendu konieczne jest obliczenie współczynników: nachylenia linii regresji $(b)=1,067$ oraz stałej regresji $(a)=-0,625$. Wskaźniki te są konieczne do wyliczenia y’ (kolumna 9), a następnie sporządzenia wykresu. 


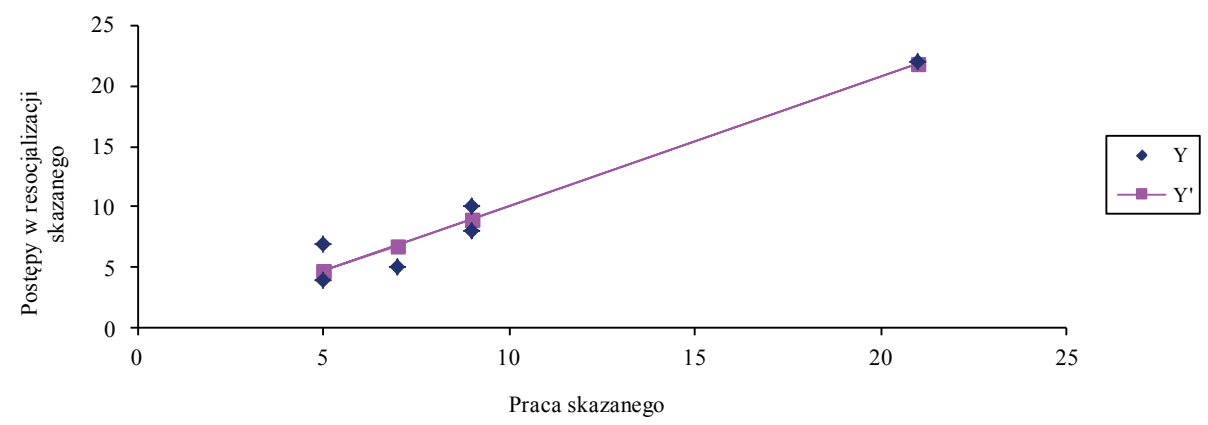

Wykres 1. Punktowy wykres rozrzutu korelacji liniowej Pearsona dwóch zmiennych: pracy i postępów w resocjalizacji skazanych ZK w Opolu Lubelskim

Źródło: opracowanie własne

Podsumowanie badania: wielkość wskaźnika Pearsona na poziomie 0,974 oznacza wysoką dodatnią korelację (zależność znaczną).

PYTANIE 2

CZY TWOIM ZDANIEM PRACA SKAZANEGO JEST RÓWNIE WAŻNA JAK ZACHOWANIE W STOSUNKU DO WSPÓŁWIĘŹNIÓW?

$x$ - ważność wykonywanej pracy przez skazanego

$y$ - ważność zachowania w stosunku do współwięźniów

Tabela pomocnicza

\begin{tabular}{|c|c|c|c|c|c|c|c|c|}
\hline \multirow{2}{*}{ Oceny } & \multirow{2}{*}{$x_{i}$} & \multirow{2}{*}{$y_{i}$} & $x_{i}-\dot{x}$ & $y_{i}-\bar{y}$ & $\left(x_{i}-\dot{x}\right)\left(y_{i}-\bar{y}\right)$ & $\left(x_{i}-\dot{x}\right)^{2}$ & $\left(y_{i}-\bar{y}\right)^{2}$ & \multirow{2}{*}{$y^{\prime}=a+b x$} \\
\hline 1 & 2 & 3 & 4 & 5 & $S S_{x y}$ & $S S_{x}$ & $S S_{y}$ & \\
\hline 1 & 7 & 5 & $-2,333$ & $-4,333$ & 10,11 & 5 & 8 & 9 \\
\hline 2 & 5 & 7 & $-4,333$ & $-2,333$ & 10,11 & 18,78 & 5,44 & 4,71 \\
\hline 3 & 9 & 8 & $-0,333$ & $-1,333$ & 0,44 & 0,11 & 1,78 & 8,98 \\
\hline 4 & 9 & 10 & $-0,333$ & 0,667 & $-0,22$ & 0,11 & 0,44 & 8,98 \\
\hline 5 & 21 & 22 & 11,667 & 12,667 & 147,78 & 136,11 & 160,44 & 21,78 \\
\hline brak & 5 & 4 & $-4,333$ & $-5,333$ & 23,11 & 18,78 & 28,44 & 4,71 \\
\hline$\sum$ & 56 & 56 & & & 191,33 & 179,33 & 215,33 & \\
\hline
\end{tabular}

Źródło: opracowanie własne

$$
r=0,307
$$




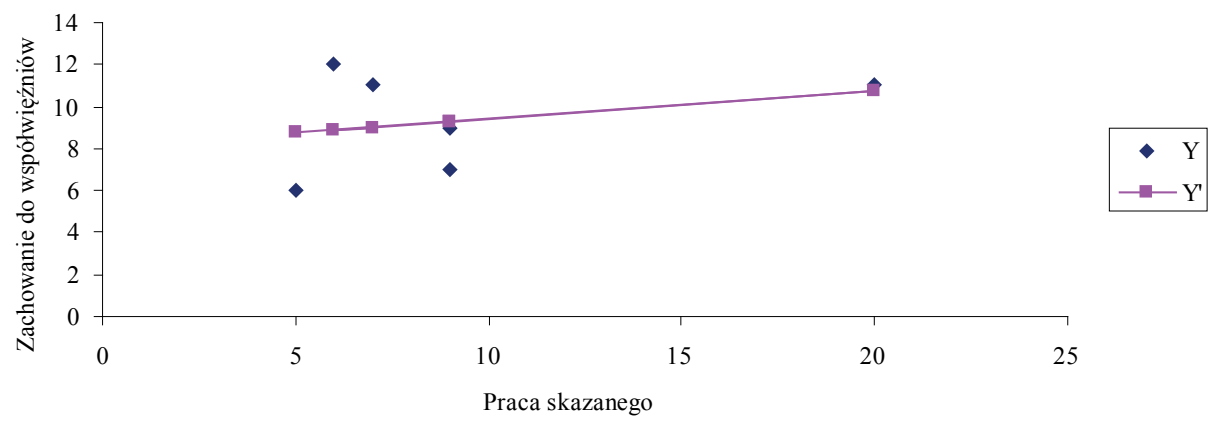

Wykres 2. Punktowy wykres rozrzutu korelacji liniowej Pearsona dwóch zmiennych: pracy i zachowania w stosunku do współwięźniów ZK w Opolu Lubelskim.

Źródło: opracowanie własne.

Podsumowanie badania: wielkość wskaźnika Pearsona na poziomie 0,307 oznacza niską dodatnią korelację (zależność wyraźna).

PYTANIE 3

CZY TWOIM ZDANIEM PRACA SKAZANEGO JEST RÓWNIE WAŻNA JAK ZACHOWANIE W STOSUNKU DO PRZEŁOŻONYCH?

$x$ - ważność pracy wykonywanej przez skazanego

$y$ - ważność zachowania w stosunku do przełożonych

Tabela pomocnicza

\begin{tabular}{|c|c|c|c|c|c|c|c|c|}
\hline \multirow{2}{*}{ Oceny } & \multirow{2}{*}{$x_{i}$} & \multirow{2}{*}{$y_{i}$} & $x_{i}-\dot{x}$ & $y_{i}-\bar{y}$ & $\begin{array}{c}\left(x_{i}-\dot{x}\right) \\
\left(y_{i}-\bar{y}\right)\end{array}$ & $\left(x_{i}-\dot{x}\right)^{2}$ & \multirow{2}{*}{$\left(y_{i}-\bar{y}\right)^{2}$} & \multirow{2}{*}{$y^{\prime}=a+b x$} \\
\cline { 5 - 8 } & & & & & $S S_{x y}$ & $S S_{x}$ & $S S_{y}$ & \\
\hline 1 & 2 & 4 & 5 & 6 & 7 & 8 & 9 \\
\hline 2 & 6 & 12 & $-3,333$ & 2,667 & $-8,89$ & 11,11 & 7,11 & 8,63 \\
\hline 3 & 9 & 8 & $-0,333$ & $-1,333$ & 0,44 & 0,11 & 1,78 & 9,26 \\
\hline 4 & 9 & 9 & $-0,333$ & $-0,333$ & 0,11 & 0,11 & 0,11 & 9,26 \\
\hline 5 & 20 & 11 & 10,667 & 1,667 & 17,78 & 113,78 & 2,78 & 11,64 \\
\hline brak & 5 & 1 & $-4,333$ & $-8,333$ & 36,11 & 18,78 & 69,44 & 8,40 \\
\hline$\sum$ & 56 & 56 & & & 32,33 & 149,33 & 113,33 & \\
\hline
\end{tabular}

Źródło: opracowanie własne.

$$
r=0,249
$$




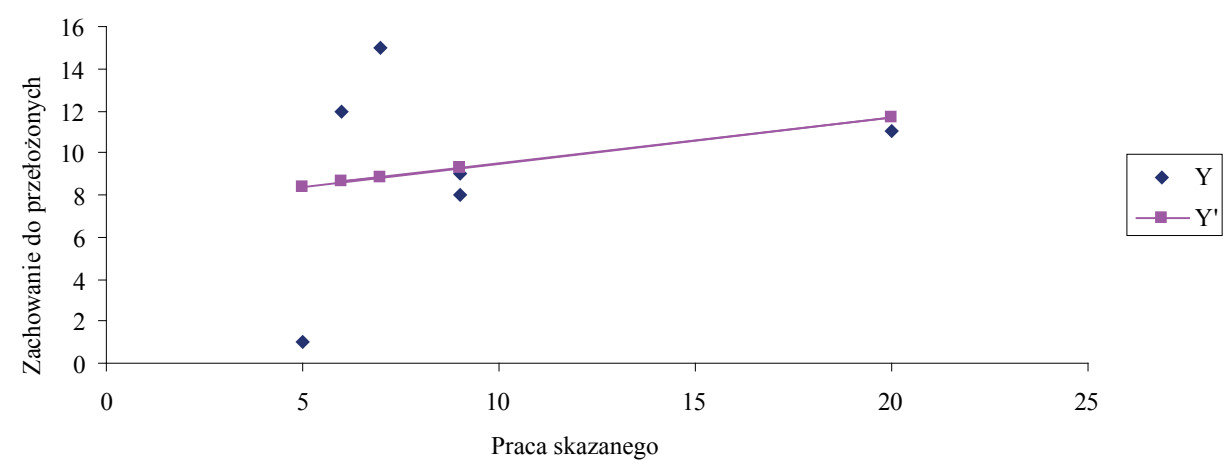

Wykres 3. Punktowy wykres rozrzutu korelacji liniowej Pearsona dwóch zmiennych: pracy i zachowania w stosunku do przełożonych ZK w Opolu Lubelskim.

Źródło: opracowanie własne.

Podsumowanie badania: wielkość wskaźnika Pearsona na poziomie 0,249 oznacza dodatnią, niską korelację (zależność wyraźna).

PYTANIE 4

CZY TWOIM ZDANIEM PRACA SKAZANEGO JEST RÓWNIE WAŻNA JAK POTRZEBA UTRZYMANIA RODZINY?

$x$ - ważność wykonywanej pracy przez skazanego

$y$ - potrzeba utrzymania rodziny

Tabela pomocnicza

\begin{tabular}{|c|c|c|c|c|c|c|c|c|}
\hline Oceny & $x_{i}$ & $y_{i}$ & $x_{i}-\dot{x}$ & $y_{i}-\bar{y}$ & $\begin{array}{c}\left(x_{i}-\dot{x}\right) \\
\left(y_{i}-\bar{y}\right)\end{array}$ & $\left(x_{i}-\dot{x}\right)^{2}$ & $\left(y_{i}-\bar{y}\right)^{2}$ & $y^{\prime}=a+b x$ \\
\cline { 5 - 8 } & & & & & $S S_{x y}$ & $S S_{x}$ & $S S_{y}$ & \\
\hline 1 & 2 & 3 & 4 & 5 & 6 & 7 & 8 & 9 \\
\hline 1 & 7 & 3 & $-2,333$ & $-6,333$ & 14,78 & 5,44 & 40,11 & 5,75 \\
\hline 2 & 6 & 3 & $-3,333$ & $-6,333$ & 21,11 & 11,11 & 40,11 & 4,21 \\
\hline 3 & 9 & 7 & $-0,333$ & $-2,333$ & 0,78 & 0,11 & 5,44 & 8,82 \\
\hline 4 & 9 & 15 & $-0,333$ & 5,667 & $-1,89$ & 0,11 & 32,11 & 8,82 \\
\hline 5 & 20 & 25 & 10,667 & 15,667 & 167,11 & 113,78 & 245,44 & 25,71 \\
\hline brak & 5 & 3 & $-4,333$ & $-6,333$ & 27,44 & 18,78 & 40,11 & 2,68 \\
\hline$\sum$ & 56 & 56 & & & 229,33 & 149,33 & 403,33 & \\
\hline
\end{tabular}

Źródło: opracowanie własne.

$$
r=0,934
$$




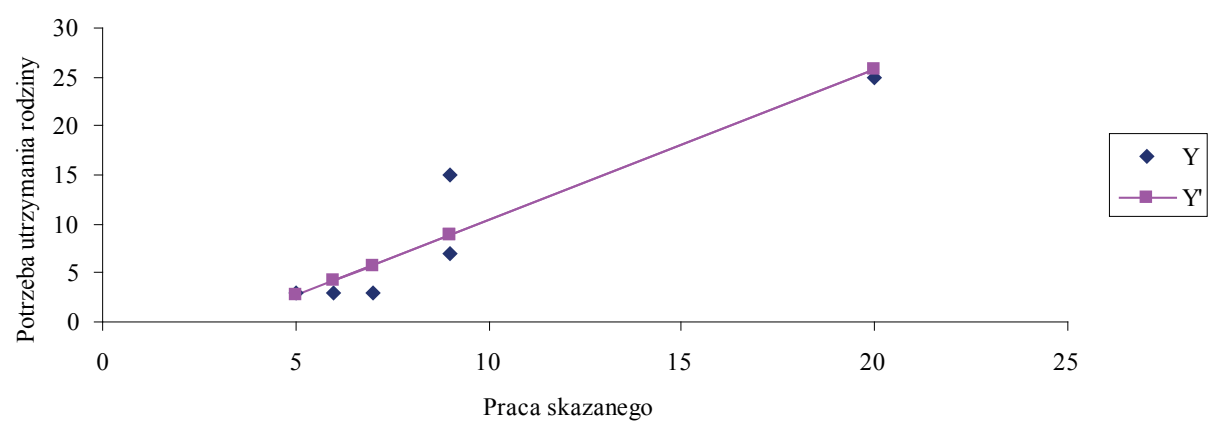

Wykres 4. Punktowy wykres rozrzutu korelacji liniowej Pearsona dwóch zmiennych: pracy skazanego i potrzeby utrzymania rodziny w ZK w Opolu Lubelskim.

Źródło: opracowanie własne.

Podsumowanie badania: wielkość wskaźnika Pearsona na poziomie 0,934 oznacza dodatnią, wysoką korelację (zależność znaczną).

\section{WNIOSKI}

Zatrudnianie więźniów to dobry pomysł, przynoszący wiele korzyści dla osadzonych w zakładach penitencjarnych. Praca stanowi rodzaj wyzwania, sprawdzenia się, często pomaga w podniesieniu samooceny. Zagospodarowanie czasu skazanym jest najważniejsze, gdyż w ten sposób odciąga się uwagę od demoralizacji w więzieniu, ponadto przygotowuje do wejścia w życie społeczne, ułatwia znalezienie pracy po opuszczeniu więzienia, otwiera perspektywy na przyszłość. Oprócz pracy ważne jest to, aby stworzyć osobom przebywającym w zakładach karnych odpowiednie warunki do kształcenia. Kursy i szkolenia do rzemieślniczych zawodów dają taką szansę, szczególnie obecnie, gdy coraz więcej pracowników wyjeżdża za granicę. Dyrektorzy zakładów karnych powinni szukać możliwości pracy dla swoich podopiecznych poza murami, na czym skorzysta także społeczeństwo. Dla pracodawców to również dogodna sytuacja, ponieważ więźniowie mogą pracować za płacę minimalną, co przy braku rąk do pracy i powszechnym dążeniu do podwyżek uposażeń za wykonywaną pracę jest bardzo istotne.

Z przeprowadzonych badań wynika bardzo istotna, dodatnia zależność między pracą skazanych z Zakładu Karnego w Opolu Lubelskim a ich stosunkiem do postępów w resocjalizacji i potrzeby utrzymania swojej rodziny oraz niska, dodatnia zależność między pracą osadzonych a ich zachowaniem w stosunku do współwięźniów i przełożonych. Są to obiecujące wyniki, ale - jak zawsze - jest nad czym pracować. 


\section{BIBLIOGRAFIA}

Czapów, Cz., Jedlewski, S. (1971). Pedagogika resocjalizacyjna. Warszawa: Wydawnictwo Naukowe PWN.

Kalinowski, M. (2008). Resocjalizacja w ujęciu pedagogicznym. Struktura procesu resocjalizacji. W: B. Urban, J.M. StaniK (red.), Resocjalizacja. Teoria i praktyka pedagogiczna (t. 1, s. 234-236). Warszawa: Pedagogium, Wydawnictwo Naukowe PWN.

KonopczyŃski, M. (2015). Pedagogika resocjalizacyjna. W stronę działań kreujacych. Kraków: Oficyna Wydawnicza „Impuls”.

KožuH, B. (2011). Statystyka dla pedagogów. Kraków: Oficyna Wydawnicza AFN.

Krajewska, A. (2001). Statystyka dla pedagogów. Białystok: Wydawnictwo Uniwersyteckie Trans Humana.

Lking, B.M., Minium, E.W. (2009). Statystyka dla psychologów i pedagogów. Tł. M. Zakrzewska, red. nauk. wyd. polskiego J. Brzeziński. Warszawa: Wydawnictwo Naukowe PWN.

PierzchaŁa, K. (2011). Resocjalizacja więźniów poprzez pracę. Więźniowie na wałach przeciwpowodziowych. W: M. Marszalek, G. Sobolewski, T. Konopka, A. Cyran (red.), Bezpieczeństwo RP w wymiarze narodowym i międzynarodowym (s. 422-427). Kielce: Szkoła Handlowa im. B. Markowskiego w Kielcach.

PierzchaŁA, K. (2013). Kapelan więzienny w procesie resocjalizacji penitencjarnej. Toruń: Wydawnictwo Adam Marszałek.

Pierzchala, K. (2016). Destygmatyzacja przestępców w świetle Magisterium Kościoła oraz poglądów na resocjalizację. Kraków: Oficyna Wydawnicza „Impuls”.

PierzchaŁa, K. (2017). Wina - prawo - kara. Prawne i psychopedagogiczne aspekty resocjalizacji penitencjarnej [Fault - Law - Penalty. Legal and Psycho and Pedagogical Aspects of Penitentiary Rehabilitation]. Probacja, 3, 91-117.

Pytka, L. (2006). Resocjalizacja. W: T. Pılch (red.), Encyklopedia pedagogiczna XXI wieku (t. 5). Warszawa: Wydawnictwo Akademickie „Żak”.

PytKa, L. (2008). Resocjalizacja i pedagogika resocjalizacyjna w ujęciu Czesława Czapówa. W: B. Urban, J.M. Stanik (red.), Resocjalizacja. Teoria i praktyka pedagogiczna (t. 1, s. 95-98). Warszawa: Pedagogium, Wydawnictwo Naukowe PWN.

\section{AKTY PRAWNE}

Rozporządzenia Ministra Sprawiedliwości z dnia 23 stycznia 2012 r. (Dz. U. z 2014 r., poz. 53).

Rozporządzenia Ministra Sprawiedliwości z dnia 30 maja 2017 r. w sprawie Funduszu Aktywizacji Zawodowej Skazanych oraz Rozwoju Przywięziennych Zakładów Pracy (Dz. U. z 2017 r., poz. 1069).

Ustawy z dnia 6 czerwca 1997 r. Kodeks karny wykonawczy (Dz. U. 1997, nr 90, poz. 557, z późn. zm.).

Ustawy z dnia 28 sierpnia 1997 r. o zatrudnianiu osób pozbawionych wolności (Dz. U. z 2014 r., poz. 1116, z późn. zm.). 
NETOGRAFIA

Blikowska, J. (2007). Korzyści z zatrudniania więźniów. Dodatek do Rzeczpospolitej, 24 lipca 2007, http://archiwum.rp.pl/artykul/719016-Korzysci-z-zatrudniania-wiezniow. html\#loginMain [dostęp: 31.12.2018].

CZSW (2018). Program „Praca dla więźniów”, https://www.sw.gov.pl/strona/ministerialny-program-pracy-wiezniow [dostęp: 31.12.2018].

ŁukAsiEwicz, A. (2018). Okresowe oceny postępów resocjalizacyjnych więźniów. Rzeczpospolita, 9.12.2016, https://www.rp.pl/Prawo-karne/312099978-Okresowe-oceny-postepow-resocjalizacyjnych-wiezniow.html [dostęp: 31.12.2018].

Statystyka (2018a). Zakład Karny w Opolu Lubelskim / Opis jednostki. https://www.sw.gov.pl/ strona/opis-zaklad-karny-w-opolu-lubelskim [dostęp: 31.12.2018].

Statystyka (2018b). Centralny Zarząd Służby Więziennej, http://www.sw.gov.pl/dzial/statystyka [dostęp: 31.12.2018].

\section{BADANIA WŁASNE KORELACJI ZMIENNYCH PRACY SKAZANEGO W KONTEKŚCIE PROCESU RESOCJALIZACJI PENITENCJARNEJ}

\section{Streszczenie}

W ujęciu polskiego prawa karnego i wykonawczego do resocjalizacji osób odbywających sankcje izolacyjne zalicza się: pracę, nauczanie, zajęcia kulturalno-oświatowe i sportowe, podtrzymywanie kontaktów z rodziną i światem zewnętrznym, nagrody i kary dyscyplinarne oraz nowe środki i metody oddziaływania na skazanych. Celem przedmiotowego przedsięwzięcia naukowego było zbadanie i ustalenie korelacji zmiennych, jakie towarzyszą skazanym w czasie podejmowanej pracy, w kontekście resocjalizacji penitencjarnej. Analizę badań przeprowadzono na podstawie wyników badań własnych, uzyskanych w sondażu diagnostycznym, przy wykorzystaniu metodologii modelowania regresji liniowej, pozwalającej na wyliczenie współzależności zmiennych, testowanie ich istotności i interpretacji wyników. Za zmienne przyjęto resocjalizację skazanych, pracę, zachowanie wobec współwięźniów oraz utrzymanie rodziny. Otrzymane wyniki powinny pozwolić na potwierdzenie znanej zależności, w której zachodzi korelacja: Praca $\rightarrow$ człowiek $\rightarrow$ relacje $\rightarrow$ skuteczność.

Słowa kluczowe: skazany; korelacja zmiennych; praca; resocjalizacja penitencjarna; rodzina; badania własne.

\section{OWN RESEARCH ON THE CORRELATION OF VARIABLES OF THE CONVICT'S WORK IN THE CONTEXT OF THE PENITENTIARY RESOCIALIZATION PROCESS}

\section{Summary}

In terms of Polish criminal law, the rehabilitation of people taking isolation sanctions includes: work, teaching, cultural-educational and sporting activities, maintaining contact with the family and the outside world, awards and disciplinary punishments as well as new means and methods of influencing the convicts. The aim of the present scientific undertaking was to investigate and establish the correlation of variables that accompany the convicts during the 
undertaken work, in the context of penitentiary resocialization. The analysis of the research was based on the results of own research, obtained in a diagnostic survey, using the linear regression modelling methodology, allowing the calculation of the interdependencies of variables, testing their significance and interpretation of results. Behind the variables, rehabilitation of convicts, work, behaviour towards fellow prisoners and family maintenance were taken. The results obtained should allow to confirm the known relationship in which correlation occurs: Work $\rightarrow$ human $\rightarrow$ relations $\rightarrow$ effectiveness.

Key words: convicted; correlation of variables; work; penitentiary rehabilitation; family; own research. 